\title{
Retinoids and Cancer: Antitumoral Effects of ATRA, 9-cis RA and the New Retinoid IIF on the HL-60 Leukemic Cell Line
}

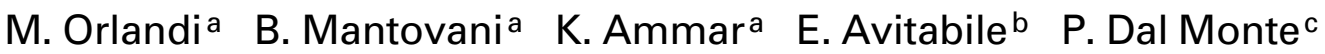 \\ G. Bartolini ${ }^{a}$ \\ aDipartimento di Biologia Evoluzionistica Sperimentale, bDipartimento di Patologia Sperimentale, e \\ 'Dipartimento di Medicina Clinica Specialistica e Sperimentale, Sezione di Microbiologia, Università di Bologna, \\ Bologna, Italia
}

Key Words

Retinoids · Cancer · Leukemia · HL-60 • IIF

\begin{abstract}
Objective: To compare the antitumoral effects of all-trans retinoic acid (ATRA) and 9-cis retinoic acid (9-cis RA) with those of 5-OH,11-O-hydrophenanthrene (IIF), a new derivative of retinoic acid. Materials and Methods: The effect of retinoids was tested on cell line HL-60. Cell differentiation and apoptosis were evaluated by morphological and biochemical analysis as $b c l-2$ protein and by DNA fragmentation assay. The ability to activate retinoic acid receptors (RAR) and/or retinoid $X$ receptors (RXR) and to modulate gene expression was determined by transactivation assay. Results: With cell line HL-60, the antiproliferative effect of IIF was stronger than that of ATRA and 9-cis RA. Following retinoid treatment, cells appeared to differentiate and apoptotic cells were observed. The appearance of DNA laddering and a decrease in the amount of $b c l-2$ protein confirmed apoptosis. IIF transcriptionally activated RXR- $\gamma$ more than RAR$\alpha$. Conclusion: The findings indicate that IIF transcriptionally activates $R X R-\gamma$ preferentially, induces apoptosis and has a more antiproliferative activity than ATRA and 9-cis RA on cell line HL-60.
\end{abstract}

Copyright $\odot 2003$ S. Karger AG, Basel

\section{Introduction}

All-trans retinoic acid (ATRA) and many of its analogs and derivatives (generally referred to as retinoids) are widely used in oncology with very good therapeutic value due to their antiproliferative and prodifferentiating effects. In particular, ATRA has been shown to be potent in inducing differentiation of acute promyelocytic leukemia (APL) blasts and as such it is used with chemotherapeutic drugs to treat APL $[1,2]$. The clinical use of retinoids has several limitations: the doses needed for successful treatment are often toxic, leading to the hypervitaminosis-A syndrome and some patients with APL eventually relapse because cancer cells become resistant to it. In order to overcome this resistance, many analogs were synthesized, which bind to the retinoic acid receptors (RAR) and/or the nuclear retinoid $\mathrm{X}$ receptors (RXR). Members of the RAR family ( $\alpha, \beta, \gamma$ and their isoforms) are activated by most physiological retinoids, among which are ATRA and 9-cis retinoic acid (9-cis RA), while members of the RXR family are activated only by 9 -cis RA $[3,4]$.

The leukemic cell lineage HL-60 is considered a good model for the study of the differentiating effect of retinoids [5]. In the presence of different agents, particularly retinoic acid, it can differentiate to monocytes or granulocytes.

\begin{tabular}{ll}
\hline KARGER & ( ) 2003 S. Karger AG, Basel \\
1011-7571/03/0123-0164\$19.50/0 \\
$\begin{array}{l}\text { Fax +4161306 1234 } \\
\begin{array}{l}\text { E-Mail karger@karger.ch } \\
\text { www.karger.com }\end{array}\end{array}$ & $\begin{array}{l}\text { Accessible online at: } \\
\text { www.karger.com } / \mathrm{mpp}\end{array}$
\end{tabular}

\author{
M. Orlandi \\ Dipartimento di Biologia Evoluzionistica Sperimentale \\ Università di Bologna, via Selmi 3 \\ I-40126 Bologna (Italy) \\ Tel. +39 0512094131, Fax +39 051251208, E-Mail orlamari@alma.unibo.it
}


Here we report the effect of 5-OH, 11-O-hydrophenanthrene, $\mathrm{C}_{17} \mathrm{H}_{20} \mathrm{O}_{2}$ (IIF), a new derivative of ATRA [6], on the proliferation, differentiation and apoptosis of HL-60 cells using morphological analysis, methylthiazoletetrazolium assay, reduction of nitro blue tetrazolium, $b c l-2$ assay and DNA fragmentation. We have also evaluated the ability of IIF to activate RAR using transactivation assay.

\section{Materials and Methods}

\section{Cell Culture and Evaluation of Cellular Morphology}

HL-60 cells were obtained from American Type Culture Collection, Rockville, Md., USA. The cells were maintained in suspension culture in RPMI 1640 medium (Sigma) supplemented with 10\% (v/v) fetal calf serum (Gibco, Grand Island, N.Y., USA), penicillin, $50 \mathrm{U} / \mathrm{ml}$, streptomycin, $50 \mathrm{mg} / \mathrm{ml}$, and glutamine, $4 \mathrm{mM}$, and grown at $37^{\circ} \mathrm{C}$ in a humidified atmosphere of $5 \% \mathrm{CO}_{2}$ in air. Trypan blue dye exclusion was used to estimate cell viability. Cells were free from mycoplasma. Exponentially growing cells were harvested by lowspeed centrifugation, then washed and resuspended in $1 \mathrm{ml}$ of RPMI. Cells were seeded $(5,000 /$ well) in 96-well plates. IIF was dissolved at $10^{-2} M$ in propylene glycol, ATRA (Sigma) and 9-cis RA (Sigma), freshly prepared each time, were dissolved at $10^{-2} M$ in ethanol. The cells were treated with IIF, ATRA or 9-cis RA. Every other day the cells were spun down, media were replaced and added with retinoids. The control cells were treated with equivalent amounts of glycol or ethanol alone. Cell proliferation was evaluated by a method based on the reduction of methylthiazoletetrazolium (Sigma), taken as an index of the number of metabolically active cells and results were expressed as percentage absorbance for treated wells/controls using the method of Denizot and Lang [7]. Differentiation was assessed by examining cell morphology with light microscopy on cytospin slides stained with May-Grünwald-Giemsa staining solution. Differentiation was also evaluated on the basis of the percentage of cells stained with 1\% safranin O (Sigma) presenting cell-associated nitro blue diformazan (NBD) deposits from the reduction of nitro blue tetrazolium (Sigma) using a previously described method [8]

\section{Transactivation Assay}

The receptor expression vectors pCMX-hRAR $\alpha$, pCMXhRAR $\beta 2$, pCMX-hRAR $\gamma$, pCMX-nRXR $\alpha$, pCMX-nRXR $\beta$ and pCMX-nRXR $\gamma$ were used. The basal reporter plasmid pAM-TREpluc containing two copies of the TRE-palindromic response element was used in transfections for RAR, while the basal reporter plasmid pTK-CRBPII-luc was used for the RXR transfections. Receptor expression vectors and basal reporter plasmids were kind gifts of Prof. R. Evans, Salk Institute for Biological Studies, La Jolla, Calif., USA. Plasmids were transiently transfected in CV-1 cells (ECACC, UK) by the lipofectamine plus method (GIBCO, Grand Island, N.Y., USA) with $40 \mathrm{ng}$ of the receptor expression plasmid vector, $200 \mathrm{ng}$ of the reporter luciferase plasmid and $360 \mathrm{ng}$ of carrier plasmid pUC19/ $5 \times 10^{4}$ cells/well in 24-well plates. The cells were transfected for $3 \mathrm{~h}$, incubated with and without IIF $100 \mathrm{n} M$ or ATRA $100 \mathrm{n} M$ for $42 \mathrm{~h}$, washed twice with PBS and treated with a lysis buffer $(25 \mathrm{~m} M$ Tris phosphate, $\mathrm{pH} 7.8 ; 8 \mathrm{mM} \mathrm{MgCl}_{2} ; 1 \mathrm{~m} M$ DTT; $1 \%$ Tritons X-100; $1 \%$ $\mathrm{BSA} ; 15 \%$ glycerol). After $30 \mathrm{~min}$, the enzymatic activity of luciferase was measured with an automated luminometer (Digene DCR-1, MGM Instruments, Conn., USA) and was expressed as relative light units per milligram of protein, as determined by the Bio-Rad method (Bio-Rad, Richmond, Calif., USA). Basal luciferase activity was determined by taking the activity obtained with the reporter plasmids and receptor expression vectors in the absence of ATRA or IIF. To control for transfection efficiency in each experiment, cells were transfected with the wild-type 760-luc vector, which contains the luc gene under the control of the HCMV major IE promoter ( -760 to +65 , kindly provided by Dr. C.V. Paya, Mayo Clinic, Rochester, N.Y., USA). Cells were transfected with $200 \mathrm{ng}$ of the wild-type 760$l u c$ and $400 \mathrm{ng}$ of pUC19/5 $\times 10^{4}$ cells and luc activity was measured $42 \mathrm{~h}$ later. Each experiment had a luciferase activity control value not lower than $1 \mathrm{SD}$ below the mean value obtained in each of the previous experiments.

\section{DNA Fragmentation Assay}

Exponentially growing cells $\left(1 \times 10^{5} / \mathrm{ml}\right.$ in T-25 flasks $)$ were treated every other day with IIF $(10 \mu M)$ or ATRA $(10 \mu M)$ and diluted every other day in order to maintain the same concentration of $1 \times 10^{5}$ cells $/ \mathrm{ml}$. The cells $\left(3 \times 10^{6} / \mathrm{sample}\right)$ were collected by centrifugation at $220 \mathrm{~g}$ for $10 \mathrm{~min}$ at $25^{\circ} \mathrm{C}$. Cell pellets were resuspended in $500 \mu \mathrm{l}$ of TE ( $10 \mathrm{~m} M$ Tris- $\mathrm{HCl}, \mathrm{pH} 8,1 \mathrm{~m} M$ EDTA, pH 8) and lysed for $1 \mathrm{~h}$ at $0-4{ }^{\circ} \mathrm{C}$ by the addition of $500 \mu \mathrm{l}$ of lysis buffer (5 mM Tris-HCl, pH 8, $20 \mathrm{~m} M$ EDTA, pH 8, 2\% Triton X-100). Samples were then centrifuged for $12 \mathrm{~min}$ at $1,000 \mathrm{~g}$, supernatants were collected in a clean microcentrifuge tube, while pellets were resuspended in $1 \mathrm{ml}$ of TE, $\mathrm{pH}$ 8. For a qualitative evaluation of DNA laddering, $0.2 \mathrm{M}$ sodium acetate and $1 \mathrm{ml}$ absolute ethanol were then added to the samples. After overnight incubation at $-20^{\circ} \mathrm{C}$, samples were centrifuged for $30 \mathrm{~min}$ at $1,000 \mathrm{~g}$. Pellets, resuspended in $100 \mu \mathrm{l}$ of TE, $\mathrm{pH} 8$, were subjected to RNAse $\left(0.5 \mu \mathrm{g} / \mathrm{ml}\right.$ at $37^{\circ} \mathrm{C}$ for $\left.1 \mathrm{~h}\right)$ and then to proteinase- $\mathrm{K}\left(1 \mu \mathrm{l} / \mathrm{ml}\right.$ at $37^{\circ} \mathrm{C}$ for $1 \mathrm{~h})$ treatment. After addition of $\times 6$ DNA loading buffer $(0.25 \%$ xylene cyanol, $0.25 \%$ bromophenol blue, $30 \%$ glycerol in water), samples were separated in a $1 \%$ agarose gel containing $0.5 \mu \mathrm{g}$ of ethidium bromide per milliliter and visualized under UV light. The DNA ladder $100 \mathrm{pb}$ (Gibco BRL) was used a molecular marker.

\section{Evaluation of bcl-2 Protein}

Expression of $b c l-2$ protein was determined by Western blotting with the use of monoclonal antibody anti-bcl-2 (Kamiya Biomedical Co., USA) in the same samples as the HL-60 cells used for DNA laddering. The cells $\left(3 \times 10^{6} / \mathrm{sample}\right)$ were collected by centrifugation at $220 \mathrm{~g}$ for $10 \mathrm{~min}$ and pellets were resuspended in PBS and sonicated on ice in the presence of protease inhibitors. Protein concentration was determined by the method of Lowry et al. [9]. Cell lysates ( $40 \mu \mathrm{g}$ of protein per lane) were size-fractioned in sodium dodecyl sulfate- $15 \%$ polyacrylamide gels prior to transfer to Hybond TM-C Extra membranes (Amersham, Italy) by standard protocols. Membranes were blocked overnight with BSA 3\% in transfer buffer saline (TBS) at $4{ }^{\circ} \mathrm{C}$. The anti- $b c l-2$ and the antimouse peroxidase conjugated antibodies were diluted $1: 100$ and $1: 3,000$, respectively, with BSA $0.1 \%$ in TBS Tween $1 \%$. The $b c l-2$ protein transferred by Western blotting was detected by ECL (Amersham). The amount of protein in each lane was the same, as confirmed by Western blotting of tubulin (not shown). 


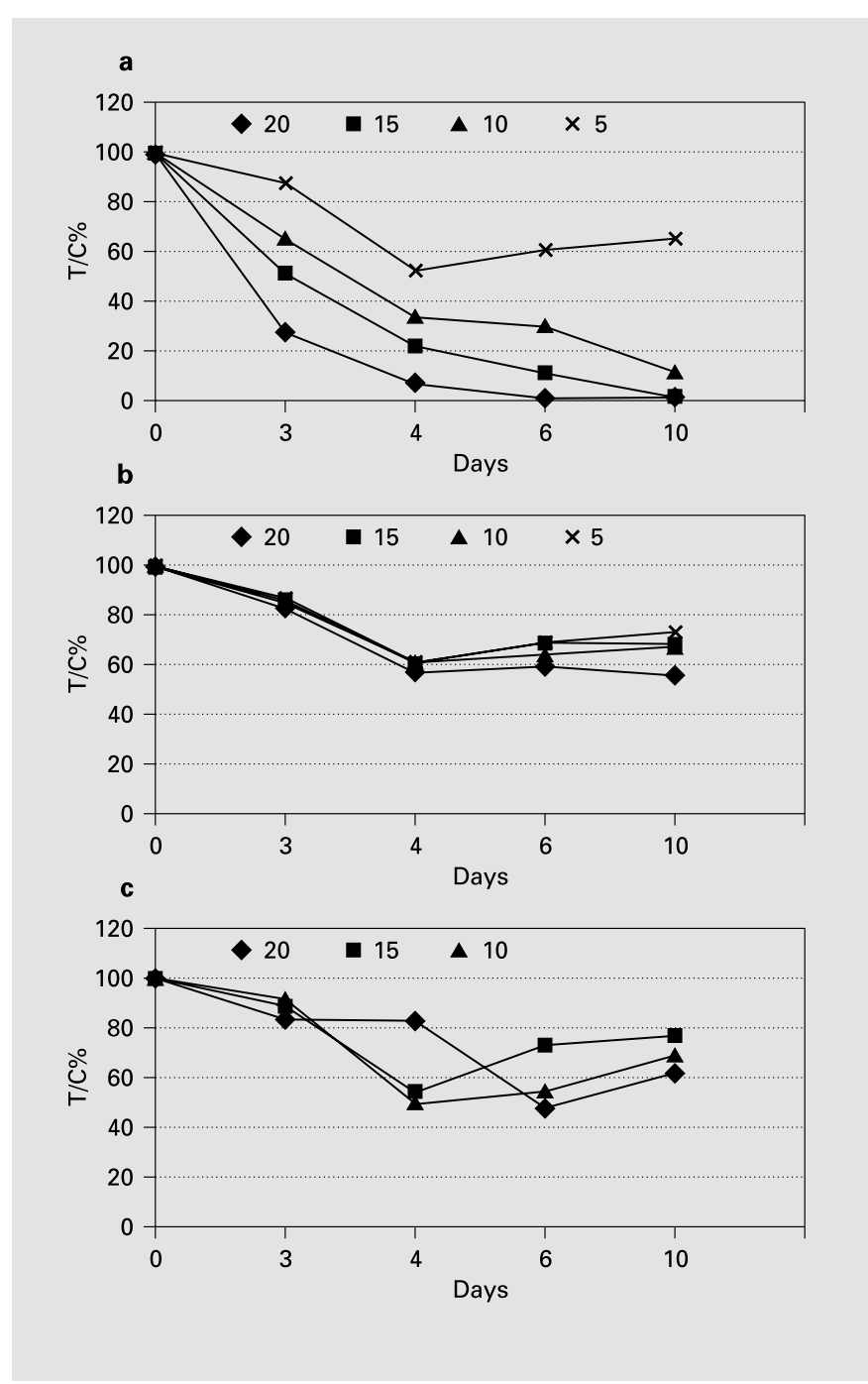

Fig. 1. Effect of IIF (a), ATRA (b) and 9-cis RA (c) on proliferation of HL-60 cells. The cells were treated every other day with various doses $(\mu M)$ of the compounds. Results are expressed as percentage absorbance for treated wells/controls. Each point is the mean \pm SEM from six replicate wells of three experiments in which $5 \times 10^{3}$ cells were plated.

\section{Results}

The antiproliferative effects of IIF, ATRA and 9-cis RA with respect to untreated exponentially growing controls on the HL-60 cell line were compared. In HL-60 cells, IIF (fig. 1a) strongly reduced proliferation in a dosedependent manner; its effect was greater than those of ATRA (fig. 1b) and 9-cis RA (fig. 1c). To evaluate whether or not the effect on proliferation was accompanied by morphological changes (indicating that cells undergo dif- ferentiation and apoptosis), cell morphology at various days of culture was analyzed. After 3 days, controls presented the typical morphology of promyelocytes and, to a lesser degree, myelocytes (fig. 2a). Following IIF or ATRA (not shown) treatment, cells appeared morphologically differentiated, with clearly lobated nuclei (fig. 2b). Functional differentiation was demonstrated by the appearance of NBD granules dispersed close to the nucleus in $15 \%$ of treated cells (fig. $2 \mathrm{c}$, d), showing the acquired capability to produce superoxide anions typical of mature granulocytes. At day 4, NBD-positive cells were 60 and $10 \%$ in treated cells and in controls, respectively (not shown). Apoptotic cells (40\% with respect to controls) could be seen from the 5 th day of culture (not shown) and became predominant (70\%) on the 8th day (fig. 2e). The presence of apoptotic cells was confirmed by the evaluation of DNA laddering (fig. 3). After 5 and 7 days of culture, DNA laddering was evident in cells treated with IIF or ATRA, but not in controls.

We evaluated the presence of $b c l-2$ proteins in HL-60 cells at different days of culture, in order to verify whether its decrease paralleled the appearance of apoptosis (fig. 4). The amount of $b c l-2$ protein decreased with respect to controls both in samples treated with IIF and ATRA and the phenomenon was more evident 7 days after treatment. These data were well correlated with those of DNA cleavage.

To discover which receptor was the target of IIF, we tested the interaction of the compound with nuclear receptors of the classes RAR and RXR by measuring its ability to stimulate the transcriptional activity of each receptor transfected with reporter genes responsive to retinoids into CV-1 cells. In preliminary experiments it was demonstrated that IIF transcriptionally activated receptors of the RXR class and in particular RXR- $\gamma$ (fig. 5a) and that it did not activate RAR- $\alpha$ receptors. In figure $5 b$ it is shown that, different from what happened using ATRA, transactivation of RXR- $\gamma$ induced by IIF was significantly higher than the basal level.

\section{Discussion}

ATRA and many analogs or derivatives of this molecule exert antiproliferative and prodifferentiating effects on a variety of transformed cells. ATRA is used in the treatment of APL in combination with chemotherapy, but its use is complicated by the fact that many patients can become resistant to the drug and that other patients develop the hypervitaminosis-A syndrome, which can even 

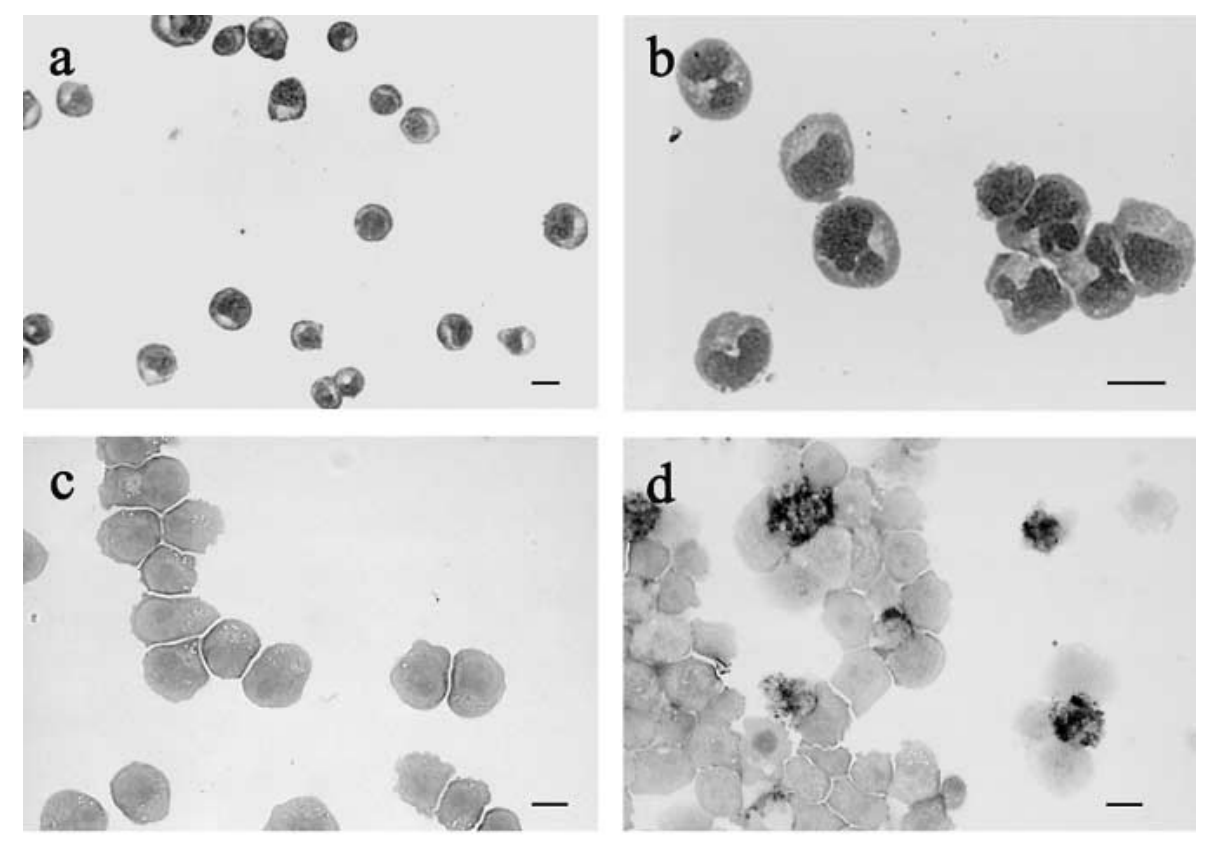

Fig. 2. Light micrographs of HL-60 cells. Cells were treated with $10 \mu M$ IIF or not and cultured for 3 days (a-d) or for 8 days (e). a Giemsa, control. b Giemsa, IIF. c Safranine O, control. d Safranine O, IIF. e Giemsa, IIF. Samples $\mathbf{c}$ and $\mathbf{d}$ were stained with safranine $\mathrm{O}$ in order to show NBD granules. Bar $=10 \mu \mathrm{m}$.

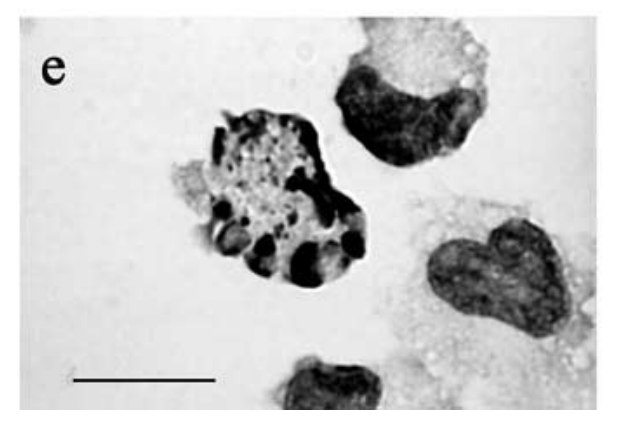

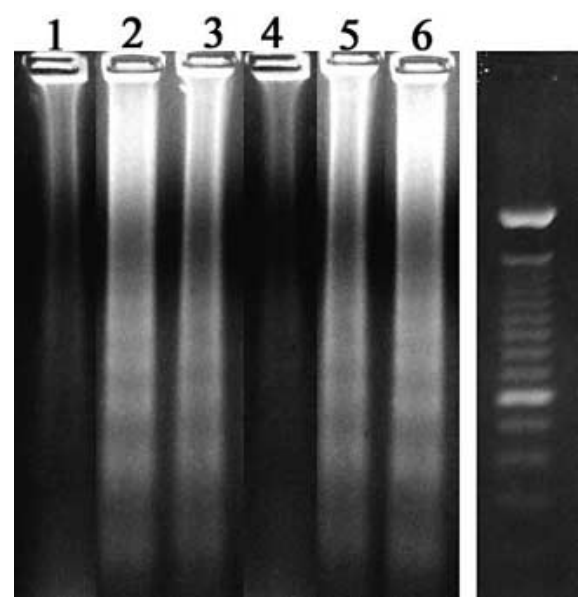

Fig. 3. DNA fragmentation in HL-60 cells treated with IIF or ATRA. HL-60 cells $\left(1 \times 10^{5} / \mathrm{ml}\right.$ in T-25 flasks) were incubated with or without $10 \mu M$ IIF or ATRA for 5 days (lane $1=$ control; lane $2=$ IIF; lane $3=$ ATRA) and 7 days (lane $4=$ control; lane $5=$ IIF; lane $6=$ ATRA $)$. The molecular markers $(100 \mathrm{pb})$ are shown to the right of the figure.

Antitumoral Effect of Retinoids

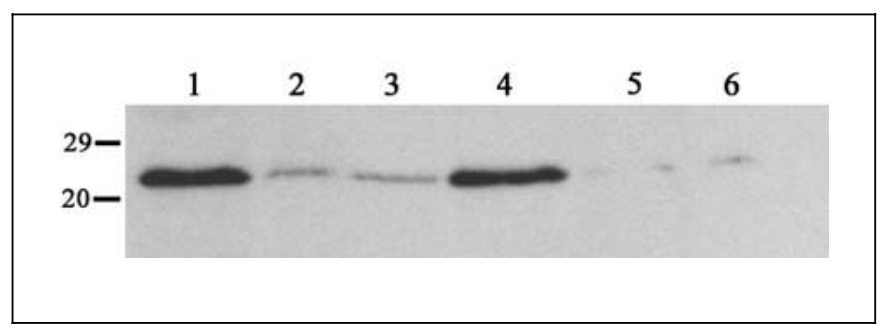

Fig. 4. $B c l-2$ protein expression in HL-60 cells. Cells $\left(1 \times 10^{5} / \mathrm{ml}\right.$ in T-25 flasks) were incubated with or without $10 \mu M$ IIF or ATRA. $B c l-2$ protein was evaluated after 5 days (lane $1=$ control; lane $2=$ IIF; lane 3 = ATRA) and 7 days (lane $4=$ control; lane $5=$ IIF; lane $6=$ ATRA).

Med Princ Pract 2003;12:164-169 


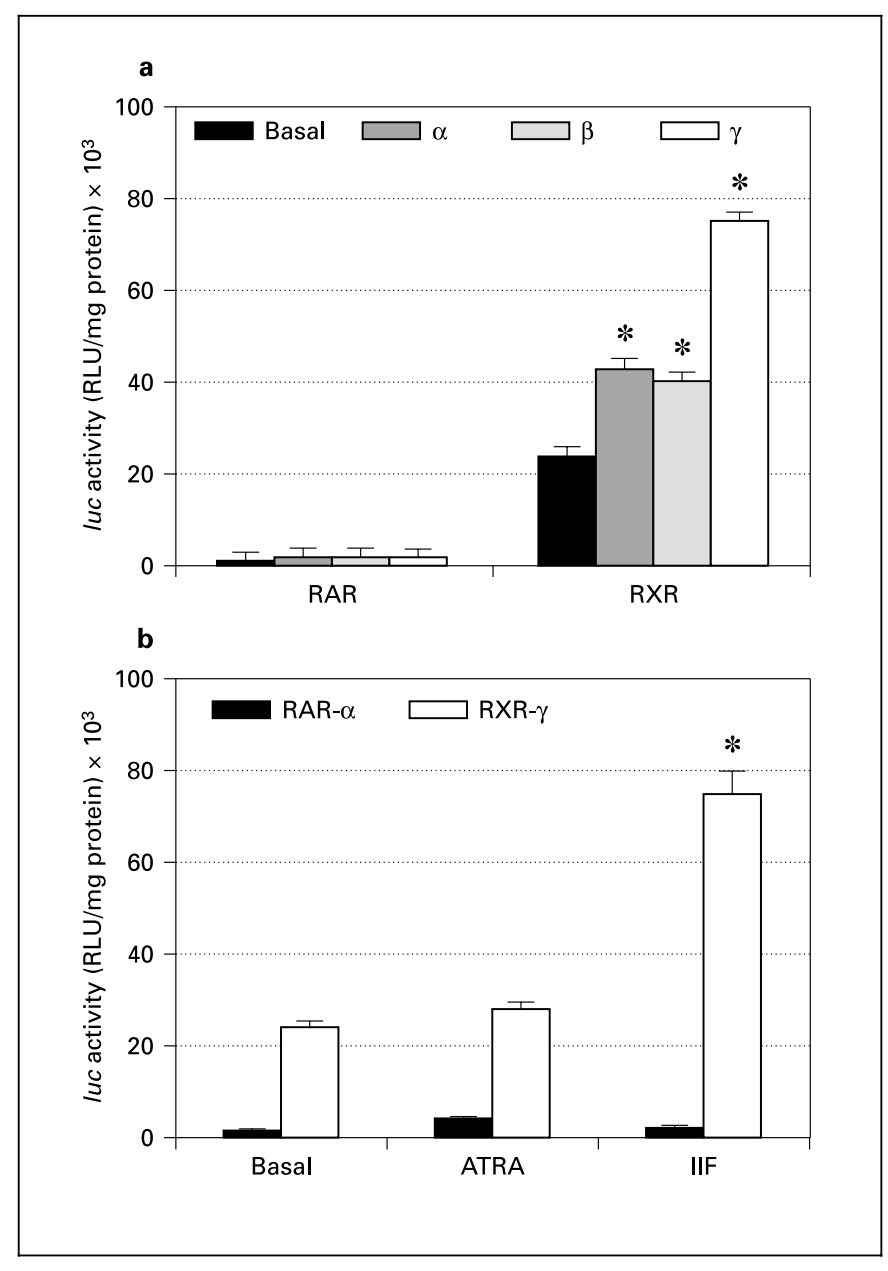

Fig. 5. Evaluation of RAR and RXR transactivation in mammalian CV-1 cells; luc activity was expressed as relative light units (RLU) per milligram of protein. Basal luciferase activity was determined by taking the activity obtained with the reporter plasmids in the absence of ATRA or IIF. The data are the mean \pm SEM from four experiments, each in duplicate. a RAR and RXR transactivation in the presence of $100 \mathrm{n} M$ IIF. b RAR- $\alpha$ and RXR- $\gamma$ transactivation in the presence of $100 \mathrm{n} M$ ATRA or IIF.

lead to death [10-13]. One approach suggested to overcome ATRA resistance is the substitution of ATRA with other retinoids, such as 9-cis RA, whose plasma levels and metabolism are different from those of ATRA, but do not present large variations, even after prolonged treatment [14]. Recently, in a patient with APL, sensitivity to the antileukemic effect of ATRA was restored by clinical treatment with an inhibitor of histone deacetylase, sodium phenylbutyrate [15]. In 30\% of APL patients, ATRA or 9-cis RA treatment causes the retinoic acid syndrome. Many mechanisms have been proposed to explain the occurrence of the syndrome, in which an important role is given to the release of vasoactive cytokines [16].

In order to find compounds for the treatment of APL that can overcome these problems, new analogs of ATRA have been synthesized, among which is IIF, a new derivative of vitamin A [6]. In HL-60 cells, IIF had a strong antiproliferative effect, higher than that of ATRA and of 9-cis RA for all the doses employed, with the exception of the $5 \mu M$ dose which, in any case, had the same efficacy of the highest doses of the other compounds. The antiproliferative effect of IIF was accompanied by morphological and biochemical changes, like the acquired capability of producing superoxide anions, clearly showing cell differentiation and apoptosis.

The presence of apoptotic cells was demonstrated not only by cell morphology, but also by the appearance, in cells treated with IIF and ATRA, of the DNA laddering typical of apoptosis and by a decrease of $b c l-2$ protein. Unlike other oncogenes, the $b c l-2$ gene and some of its family members, rather than cell proliferation, promote cell survival by preventing programmed cell death [17, 18]. $\mathrm{Bcl}-2$ protein overexpression has been demonstrated in many tumor cells and has been found to be inversely related to the apoptotic cell index [19-22]. Similar to these data, we have found that, in HL-60 cells, the decrease of $b c l-2$ protein induced by IIF and ATRA was well correlated with the laddering of DNA.

9-cis RA has been found to be a high-affinity ligand for RXR receptors, which form heterodimers with other hormone receptors, thus influencing the level of transcription of target genes [23, 24]. In addition, 9-cis RA binds to RAR with the same affinity as ATRA [25] and may influence gene transcription in this way as well. In contrast, ATRA directly activates only the RAR, and its RXR-stimulating activities, shown in in vivo transactivation assays, are probably due to its conversion to 9-cis RA under in vivo conditions [23]. In HL-60, apoptosis was observed only when cells were treated with agents capable of activating both RAR and RXR [26]. Under the experimental conditions it appears that IIF, even though it transcriptionally activates RXR- $\gamma$ preferentially, was also able to induce apoptosis. This effect could be due to minimal transcriptional activation of RAR or to a conversion into a compound able to transcriptionally activate RAR under culture conditions. 


\section{Conclusion}

Our findings show that the new derivative of retinoic acid, IIF, has good antiproliferative and prodifferentiating properties in cells of the leukemic lineage HL-60 and demonstrate that IIF transcriptionally activates RXR- $\gamma$ preferentially. RXR is the receptor class which binds 9-cis RA and induces apoptosis in HL-60 cells.

\section{Acknowledgments}

The present work was supported by grants from the Research Program entitled 'Differenziamento Cellulare', University of Bologna, to G.B.

The authors thank Prof. R.M. Evans for his kind gift of receptor expression vectors and basal reporter plasmids, Ms. L. Di Pietrangelo for expert photographic assistance and Ms. C. Castagnotto for help in the preparation of the manuscript.

\section{References}

1 Chomienne C, Balitrand N, Ballerini P, Castaigne $\mathrm{S}$, de Thé $\mathrm{H}$, Degos L: All-trans retinoic acid modulates the retinoic acid receptor alpha in promyelocytic cells. J Clin Invest 1991;88: 2150-2154.

2 Warrell RP: Pathogenesis and management of acute promyelocytic leukaemia. Annu Rev Med 1996;47:555-565.

3 Kliewer SA, Umesono K, Mangelsdorf DJ, Evans RM: Retinoid X receptor interacts with nuclear receptors in retinoic acid, thyroid hormone and vitamin D3 signalling. Nature 1992 355:446-452.

4 Giguere V, Ong ES, Segui P, Evans RM: Identification of a receptor for morphogen retinoic acid. Nature 1987;330:624-629.

5 Martin SJ, Bradley JG, Cotter TG: HL-60 cells induced to differentiate towards neutrophils subsequently die via apoptosis. Clin Exp Immunol 1990:79:448-453.

6 Ammar K: Derivatives of Phenanthrene for Medicinal Use and a Process for Their Preparation. International patent application. WO 00/ 17143. World Intellectual Property Organization, 2000.

7 Denizot F, Lang R: Rapid colorimetric assay for cell growth and survival: Modifications to the tetrazolium dye procedure giving improved sensitivity and reliability. J Immunol Methods 1986;89:271-277.

8 Breitman TR: Growth and differentiation of human myeloid leukaemia cell line HL-60. Methods Enzymol 1990;190:118-130.

9 Lowry OH, Rosebrough NJ, Farr AL, Randall RJ: Protein measurement with the Folin phenol reagent. J Biol Chem 1951;193:265-275.

10 Smith MA, Parkinson DR, Cheson BD, Friedman MA: Retinoids in cancer therapy. J Clin Oncol 1992;10:839-864.
11 Muindi J, Frankel SR, Miller WH Jr, Jakubowski A, Scheinberg DA, Young CW, Dmitrovsky E, Warrell RP Jr: Continuous treatment with all-trans retinoic acid causes a progressive reduction in plasma drug concentrations: Implications for relapse and retinoid resistance in patients with acute promyelocytic leukaemia. Blood 1992;79:299-303.

12 Delva L, Cornic M, Balitrand N, Guidez F, Micléa JM, Delmer A, Teillet F, Fenaux P, Castaigne S, Degos L, Chomienne C: Resistance to all-trans retinoic acid (ATRA) therapy in relapsing acute promyelocytic leukaemia: Study of in vitro ATRA sensitivity and cellular retinoic acid binding protein levels in leukaemic cells. Blood 1993;82:2175-2181.

13 Zhou DC, Hallam SJ, Lee SJ, Klein RS, Wiernik PH, Tallman MS, Gallagher RE: Constitutive expression of cellular retinoic acid binding protein II and lack of correlation with sensitivity to all-trans retinoic acid in acute promyelocytic leukaemia cells. Cancer Res 1998;58: 5770-5776.

14 Miller WH Jr, Jakubowski A, Tong WP, Miller VA, Rigas JR, Benedetti F, Gill GM, Truglia JA, Ulm E, Shirley M: 9-cis retinoic acid induces complete remission but does not reverse clinically acquired retinoid resistance in acute promyelocytic leukemia. Blood 1995;85:30213027.

15 Warrell RP Jr, He LZ, Richon V, Calleja E, Pandolfi PP: Therapeutic targeting of transcription in acute promyelocytic leukaemia by use of an inhibitor of histone deacetylase. $\mathrm{J}$ Natl Cancer Inst 1998;90:1621-1625.

16 Vadhat L, Maslak P, Miller WH Jr, Eardley A, Heller G, Scheinberg DA, Warrell RP Jr: Early mortality and the 'retinoic acid syndrome' in acute promyelocytic leukemia: Impact of leukocytosis, low-dose chemotherapy, PMN/ RAR-alpha isoform, and CD13 expression in patients treated with all-trans retinoic acid. Blood 1994;84:3843-3849.
17 Veis DJ, Sorenson CM, Shutter JR, Korsmeyer $\mathrm{SJ}$ : Bcl-2-deficient mice demonstrate fulminant lymphoid apoptosis, polycystic kidneys, and hypopigmented hair. Cell 1993;75:229-240.

18 Zamzami N, Susin SA, Marchetti P, Hirsch T, Gòmez-Monterrey I, Castedo M, Kroemer G: Mitochondrial control of nuclear apoptosis. J Exp Med 1996;183:1533-1544.

19 Leek RD, Kaklamanis L, Pezzella F, Gatter $\mathrm{KC}$, Harris AL: $b c l-2$ in normal human breast and carcinoma, association with estrogen receptor-positive, epidermal growth factor receptor-negative tumours and in situ cancer. $\mathrm{Br} \mathrm{J}$ Cancer 1994;69:135-139.

20 Chan WK, Poulsom R, Lu QJ, Patel K, Gregory K, Fisher CJ, Hanby AM: Bcl-2 expression in invasive mammary carcinoma: Correlation with apoptosis, hormone receptors and p53 expression. J Pathol 1993;169(suppl):138-140.

21 Del Bufalo D, Biroccio A, Leonetti C, Zupi G: $\mathrm{Bcl}-2$ overexpression enhances the metastatic potential of a human breast cancer line. FASEB J 1997;11:947-953.

22 Furuya Y, Krajewski S, Epstein JI, Reed JC, Isaacs JT: Expression of $b c l-2$ and the progression of human and rodent prostatic cancers. Clin Cancer Res 1996;2:389-398.

23 Heyman RA, Mangelsdorf DJ, Dyck JA, Stein RB, Eichele G, Evans RM, Thaller C: 9-cis retinoic acid is a high affinity ligand for the retinoid X receptor. Cell 1992;68:397-406.

24 Minucci S, Zand DJ, Dey A, Marks MS, Nagata T, Grippo JF, Ozato K: Dominant negative retinoid $X$ receptor $\beta$ inhibits retinoic acidresponsive gene regulation in embryonal carcinoma cells. Mol Cell Biol 1994;14:360-372.

25 Mangelsdorf DJ: Vitamin A receptors. Nutr Rev 1994;52:S32-S44.

26 Nagy L, Thomàzy VA, Shipley GL, Fésus L, Lamph W, Heyman RA, Chandraratna RAS, Davies PJ: Activation of retinoid $\mathrm{X}$ receptors induces apoptosis in HL-60 cell lines. Mol Cell Biol 1995;15:3540-3551. 